\title{
Thapsigargin-sensitive $\mathrm{Ca}^{2+}$-ATPases account for $\mathrm{Ca}^{2+}$ uptake to inositol 1,4,5-trisphosphate-sensitive and caffeine-sensitive $\mathrm{Ca}^{2+}$ stores in adrenal chromaffin cells
}

\author{
Jens-Christian J. POULSEN, ${ }^{\star}$ Casper CASPERSEN, ${ }^{\star}$ Dorte MATHIASEN, ${ }^{\star}$ J. Malcolm EAST, $\dagger$ Richard E. A. TUNWELL, $\ddagger$ \\ F. Anthony LAI, $\ddagger$ Nobuaki MAEDA, $\S$ Katsuhiko MIKOSHIBA $\S$ and Marek TREIMAN ${ }^{\star} \|$ \\ *Department of Medical Physiology and Biotechnology Center for Signal Peptide Research, Panum Institute, University of Copenhagen, Copenhagen, Denmark, \\ †Department of Biochemistry, University of Southampton, Southampton, U.K., ‡National Institute for Medical Research, Mill Hill, London, U.K., \\ and §The Institute of Medical Science, Tokyo, Japan
}

In chromaffin cells of adrenal medulla, heterogeneity of $\mathrm{Ca}^{2+}$ stores has been suggested with respect to the mechanisms of $\mathrm{Ca}^{2+}$ uptake and release. We have examined $\mathrm{Ca}^{2+}$-ATPases responsible for loading of $\mathrm{Ca}^{2+}$ stores in these cells for their sensitivity to thapsigargin, a highly selective inhibitor of the SERCA [sarco(endo)plasmic reticulum calcium ATPase] family of intracellular $\mathrm{Ca}^{2+}$ pumps. Using immunostaining, we studied the distribution of $\mathrm{Ca}^{2+}$-ATPases, and of receptors for inositol 1,4,5-trisphosphate $\left(\operatorname{Ins} P_{3}\right)$ and ryanodine, in the density-gradient fractions of microsomes from bovine adrenal medulla. In parallel, we examined distribution profiles of ATP-dependent $\mathrm{Ca}^{2+}$ uptake in the same fractions, along with subcellular markers for plasma membranes and endoplasmic reticulum (ER). Two $\mathrm{Ca}^{2+}$-ATPaselike proteins (116 and $100 \mathrm{kDa})$ were detected, consistent with the presence of SERCA $2 \mathrm{~b}$ and SERCA 3 isoenzymes of $\mathrm{Ca}^{2+}$ pumps. The distribution of these putative $\mathrm{Ca}^{2+}$-ATPase iso- enzymes paralleled that of $\operatorname{Ins} P_{3}$ and ryanodine receptors. This distribution of ER $\mathrm{Ca}^{2+}$-ATPases, as determined immunologically, was consistent with that of thapsigargin-sensitive, but not of thapsigargin-insensitive, ATP-dependent $\mathrm{Ca}^{2+}$ uptake. In contrast, the distribution profile of the thapsigargin-insensitive $\mathrm{Ca}^{2+}$ uptake was strongly correlated to that of plasma membranes, and co-distributed with plasma membrane $\mathrm{Ca}^{2+}$-ATPase detected immunologically. In isolated, permeabilized chromaffin cells, Ins $P_{3}$ and caffeine induced $\mathrm{Ca}^{2+}$ release following an ATPdependent $\mathrm{Ca}^{2+}$ accumulation to the stores. This accumulation was abolished by thapsigargin. Together, these data strongly indicate that the thapsigargin-sensitive, presumably SERCAtype $\mathrm{Ca}^{2+}$-ATPases account for $\mathrm{Ca}^{2+}$ uptake to Ins $P_{3}$-sensitive, as well as to caffeine-sensitive, $\mathrm{Ca}^{2+}$ stores in bovine adrenal chromaffin cells.

\section{INTRODUCTION}

$\mathrm{Ca}^{2+}$ stores play an important role in compartmentalization of intracellular $\mathrm{Ca}^{2+}$ in most, if not all, types of cells [1-3]. This compartmentalization is necessary to enable the cell to respond with reversible elevation of cytosolic free $\mathrm{Ca}^{2+}$ to a wide range of stimuli, as well as to maintain submicromolar concentrations of $\mathrm{Ca}^{2+}$ in the cell cytosol. The ATP-dependent loading of the stores with $\mathrm{Ca}^{2+}$ from the cytosol is accomplished by ATP-dependent $\mathrm{Ca}^{2+}$ pumps. The Sarco(Endo)plasmic Reticulum $\mathrm{Ca}^{2+}$-ATPase (SERCA ATPase) family [4] represents one class of such pumps. The $\mathrm{Ca}^{2+}$ channels of the stores, associated with receptors for inositol 1,4,5-trisphosphate $\left(\operatorname{Ins} P_{3}\right)$ [5] or ryanodine [6] are responsible for stimulus-induced, transient events of $\mathrm{Ca}^{2+}$ efflux from the stores, to generate cytosolic $\mathrm{Ca}^{2+}$ signals [2,3]. In many cell types, such agonist-induced $\mathrm{Ca}^{2+}$ signalling events take the form of complex spatiotemporal waves [2]. Since these $\mathrm{Ca}^{2+}$ signals are dependent on the molecular properties, organization and distribution of $\mathrm{Ca}^{2+}$ store compartments and their key proteins, including $\mathrm{Ca}^{2+}$ channels and $\mathrm{Ca}^{2+}$ pumps, understanding the organization of $\mathrm{Ca}^{2+}$ stores on the molecular and cellular level would afford a better insight into the $\mathrm{Ca}^{2+}$ signalling process.
Chromaffin cells of adrenal medulla have served as one model system in which to study molecular and functional heterogeneity of $\mathrm{Ca}^{2+}$ stores [7-12]. One level of this heterogeneity involves the presence of at least two types of $\mathrm{Ca}^{2+}$-release channel proteins in the stores, i.e. those representing the Ins $P_{3}$ receptor and ryanodine receptor (the caffeine-sensitive receptor) families. A spatial separation of $\mathrm{Ca}^{2+}$ signals evoked through each of the two receptors has been observed, with $\mathrm{Ca}^{2+}$ release due to the activation of Ins $P_{3}$ receptors in cultured chromaffin cells restricted only to the perinuclear area, and caffeine-invoked $\mathrm{Ca}^{2+}$ release occurring over the entire cell [7]. These phenomena raise a number of issues regarding the organization of $\mathrm{Ca}^{2+}$ stores. Some of the important questions are: are the Ins $P_{3}$ and ryanodine receptors localized to the same, or distinct store compartments? Is $\mathrm{Ca}^{2+}$ loading to the stores dependent on one, or several types of $\mathrm{Ca}^{2+}$ pumps? Work using thapsigargin, a potent and selective inhibitor of SERCAtype $\mathrm{Ca}^{2+}$-ATPases $[13,14]$, has suggested the presence in chromaffin cells of thapsigargin-sensitive $[9,12,15-17]$, as well as thapsigargin-insensitive, $\mathrm{Ca}^{2+}$-ATPases, the latter postulated to be responsible for $\mathrm{Ca}^{2+}$ loading to caffeine-sensitive $\mathrm{Ca}^{2+}$ stores [10].

In the present study we have examined thapsigargin sensitivity of $\mathrm{Ca}^{2+}$-ATPases associated with the Ins $P_{3}$-sensitive and caffeine-

Abbreviations used: $\mathrm{C}_{12} \mathrm{E}_{8}$, dodecyl octaoxyethyleneglycol; $\mathrm{ER}$, endoplasmic reticulum; $\mathrm{HB}$, homogenization buffer; Ins $P_{3}$, inositol 1,4,5-trisphosphate; PMCA, plasma membrane calcium ATPase; PVDF, poly(vinylidene difluoride); RSA, relative specific activity; SERCA, sarco(endo)plasmic reticulum calcium ATPase; TES, $\mathrm{N}$-tris(hydroxymethyl)methyl-2-aminomethanesulphonic acid.

$\|$ To whom correspondence should be addressed. 
sensitive $\mathrm{Ca}^{2+}$ stores in chromaffin cells by two independent approaches. In subcellular fractionation of adrenal medulla microsomes, we used functional assays and immunodetection of the key $\mathrm{Ca}^{2+}$-store proteins (i.e. $\mathrm{Ca}^{2+}$ pumps and $\mathrm{Ca}^{2+}$ channels) along with the measurements of thapsigargin-sensitive and -insensitive components of the ATPase-dependent $\mathrm{Ca}^{2+}$ uptake. In isolated, permeabilized chromaffin cells we further tested the main conclusions from subcellular fractionation. Together, the data from both approaches show that the loading of $\mathrm{Ca}^{2+}$ to Ins $P_{3}$-sensitive and caffeine-sensitive stores is dependent on $\mathrm{Ca}^{2+}$ pumps sensitive to thapsigargin which are likely to include SERCA $2 \mathrm{~b}$ and SERCA 3 members of the SERCA family of intracellular ATPases.

\section{MATERIALS AND METHODS}

\section{Preparation of subcellular fractions}

The total microsomal fraction (P3) of bovine adrenal glands was prepared using the differential centrifugation protocol described previously [17]. P3 fraction was stored in homogenization buffer

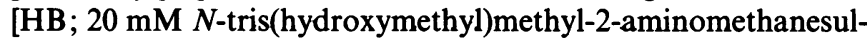
phonic acid (TES), $\mathrm{pH} 7.0,300 \mathrm{mM}$ sucrose] at $-80^{\circ} \mathrm{C}$ until required for further fractionation. For density fractionation, $7.5 \mathrm{ml}$ of the $\mathrm{P} 3$ fraction (4.5-5.5 $\mathrm{mg}$ of protein/ml) in $\mathrm{HB}$ was applied on top of a discontinuous sucrose gradient consisting of $10 \mathrm{ml}$ layers of $50 \%, 30 \%$ and $17 \%(\mathrm{w} / \mathrm{v})$ sucrose in $20 \mathrm{mM}$ TES (pH 7.0). Up to four gradients were centrifuged at $95000 g_{\text {av }}$ for $17 \mathrm{~h}$ (Beckman SW28 rotor). Fractions were collected from the top, specified by the following volumes (in $\mathrm{ml}$; fraction numbers 1-7 respectively): 7.5, 3.7, 4.0, 6.0, 3.0, 7.0 and 6.3. Fraction 8 was the material pelleted through the gradient and resuspended in $50 \%(\mathrm{w} / \mathrm{v})$ sucrose. The fractions were stored at $-80^{\circ} \mathrm{C}$. Sarcoplasmic reticulum vesicles from rabbit skeletal muscle were prepared according to De Meis and Hasselbach [18], and stored in $\mathrm{HB}$ at $-80^{\circ} \mathrm{C}$.

\section{SDS/PAGE and immunoblot analysis}

SDS/PAGE was carried out [19] using $4 \%$ stacking (pH 6.7) and either $5 \%$ (Ins $P_{3}$ and ryanodine receptor) or $8 \%$ (plasma membrane $\mathrm{Ca}^{2+}$-ATPase) separating ( $\mathrm{pH} \mathrm{8.9)}$ gels, and 15,40 or $60 \mu \mathrm{g}$ of protein on each lane for the analysis of plasma membrane $\mathrm{Ca}^{2+}$-ATPase, endoplasmic reticulum (ER) $\mathrm{Ca}^{2+}$-ATPases, or Ins $P_{3}$ or ryanodine receptors respectively. For SERCA Ca ${ }^{2+}$ ATPase immunoblots, SDS/8\%-PAGE was as described before [17]; however, to increase the resolution in the molecular-mass region of $\mathrm{Ca}^{2+}$-ATPases, the electrophoresis was extended past the exit of the dye front from the gel. In control experiments, no immunoreactive bands at the bottom of the gel were observed. Immunostaining for $\mathrm{ER} \mathrm{Ca}^{2+}$-ATPases was carried out by means of the monoclonal antibody Y/1F4 [20], and for plasma membrane $\mathrm{Ca}^{2+}$-ATPase by means of the monoclonal antibody MA3914 (Affinity Bioreagents, Neshanic Station, NJ, U.S.A.), and a protocol described earlier [17]. For analysis of $\operatorname{Ins} P_{3}-$ and ryanodine-receptors following SDS/5\%-PAGE, transfer of separated proteins on to poly(vinylidene difluoride) (PVDF) membranes was as described previously [21], and blots were then probed with rabbit anti-(peptide) sera specific for the mammalian Ins $P_{3}$ and ryanodine receptors (R. E. A. Tunwell and F. A. Lai, unpublished work). For comparison, some of the blots were also probed with rat monoclonal antibody raised against mouse cerebellar Ins $P_{3}$ receptor [22,23]. The blots were developed using the enhanced chemiluminescence technique (ECL kit, Amersham). Rabbit brain and heart muscle microsomes $(20 \mu \mathrm{g})$ were used in positive control lanes of the immunoblots in order to demonstrate the specificity of the mammalian Ins $P_{3}$ and ryanodine receptor antibodies respectively.

\section{Measurements of ${ }^{45} \mathrm{Ca}^{2+}$ uptake}

Uptake of ${ }^{45} \mathrm{Ca}^{2+}$ was measured by means of a filtration assay. Membrane protein $(30 \mu \mathrm{g})$ was incubated in $1 \mathrm{ml}$ of a medium containing (concentrations in $\mathrm{mM}$ ): TES, 20 ( $\mathrm{pH} \mathrm{7.0);} \mathrm{sucrose,}$ 27; $\mathrm{KCl}, 116 ; \mathrm{MgCl}_{2}, 1 ; \mathrm{CaCl}_{2}, 7.8 \times 10^{-3}$ (including ${ }^{45} \mathrm{CaCl}_{2}$ at a specific radioactivity of $60 \mathrm{Ci} / \mathrm{mol}$ ); EGTA, $50 \times 10^{-3}$; ATP, 2; and, where appropriate, inhibitors thapsigargin.(in $0.5 \%$ DMSO) or vanadate (in TES). Where appropriate, $0.5 \%$ (v/v) DMSO was added to control incubations. Free concentrations of $\mathrm{Ca}^{2+}$ and $\mathrm{Mg}^{2+}$ were $55 \mathrm{nM}$ and $100 \mu \mathrm{M}$ respectively. (These free ion concentrations were calculated by means of a computer program kindly provided by Drs. M. Gratzl and K. Föhr, University of Ulm, Germany [24]). In experiments with vanadate, the total $\mathrm{Mg}^{2+}$ concentration used was $7 \mathrm{mM}$ ( $5 \mathrm{mM}$ free), to increase the vanadate sensitivity of the ATPases. The incubations were started by adding ATP (or an identical volume of TES) to the assay mixture and transferring the tubes from ice to a $37^{\circ} \mathrm{C}$ bath. After $60 \mathrm{~min}$ the incubation mixture was filtered using a Brandel Harvester M24 apparatus (SEMAT Technical Ltd., UK) equipped with Whatman GF/F filters precoated with polyethyleneimine. The filters were washed twice with an ice-cold buffer containing (concentrations in $\mathrm{mM}$ ): $\mathrm{NaCl}, 140 ; \mathrm{MgCl}_{2}, 10$; Tris/HCl, 20 (pH 7.0); and counted using Opti-Fluor (Packard Instruments, DK) scintillation liquid at $100 \%$ efficiency.

ATP-dependent $\mathrm{Ca}^{2+}$ uptake was defined as the difference between the ${ }^{45} \mathrm{Ca}^{2+}$ retained on the filters following incubations in the presence and absence of ATP respectively. (In the absence of ATP, the background radioactivity was 5-10\% of the total uptake.) The thapsigargin-insensitive component of ${ }^{45} \mathrm{Ca}^{2+}$ uptake was defined as the ATP-dependent uptake in the presence of $100 \mathrm{nM}$ thapsigargin. The thapsigargin-sensitive component of ${ }^{45} \mathrm{Ca}^{2+}$ uptake was defined as the difference between the total and the thapsigargin-insensitive ${ }^{45} \mathrm{Ca}^{2+}$ uptake. The distribution of these two $\mathrm{Ca}^{2+}$ uptake components on density gradient is reported in a manner analogous to that used for subcellular markers (see below).

\section{Measurements of $\mathrm{Ca}^{2+}$-dependent ATPase activity}

$\mathrm{Ca}^{2+}$-dependent ATPase activity was measured in a coupled enzyme assay essentially as described by Michelangeli et al. [25]. The basic reaction mixture (at $37^{\circ} \mathrm{C}$, final volume $1 \mathrm{ml}$ ) contained (concentrations in $\mathrm{mM})$ : Hepes, $40(\mathrm{pH} 7.0) ; \mathrm{KCl}, 100 ; \mathrm{MgSO}_{4}$, 5; phosphoenolpyruvate, 0.21 ; NADH, 0.15; and ATP, 2.1. Pyruvate kinase and lactate dehydrogenase were present at 30 and $90 \mathrm{units} / \mathrm{ml}$ respectively. For each condition, activities of $100 \mu \mathrm{g}$ of adrenal medulla microsomes, or $1 \mu \mathrm{g}$ of muscle sarcoplasmic reticulum, were measured. The rate of absorbance change at $340 \mathrm{~nm}$ was recorded and converted into $\mu \mathrm{mol}$ of NADH consumed using a molar absorption coefficient of 5070 $\mathrm{M}^{-1} \cdot \mathrm{cm}^{-1}$, as determined for the actual assay conditions. ATPdependent activity was defined as the difference between the rates of NADH consumption measured after and before the addition of ATP, and was expressed as $\mu \mathrm{mol}$ of ATP hydrolysed $/ \mathrm{min}$ per $\mathrm{mg}$ of protein. $\mathrm{Ca}^{2+}$-dependent ATPase activity was defined as the difference between the ATP-dependent activities in the presence of $50 \mu \mathrm{M} \mathrm{Ca}^{2+}$ and $4 \mathrm{mM}$ EGTA respectively. When actions of thapsigargin, $\mathrm{Ca}^{2+}$ ionophore A23187, or dodecyl octaoxyethyleneglycol $\left(C_{12} E_{8}\right)$ were tested, equal amounts of these agents were present in $\mathrm{Ca}^{2+}$ - and EGTA-containing cuvettes. Student's $t$-test was used for statistical comparisons between the means of activities under different conditions. 


\section{Assays of subcellular markers}

The ouabain-sensitive $\mathrm{Na}^{+}, \mathrm{K}^{+}$-ATPase, NADPH-cytochrome $c$ reductase [in the presence of $1.5 \mu \mathrm{M}$ rotenone, $0.3 \mathrm{mM} \mathrm{KCN}$ and $0.008 \%(\mathrm{v} / \mathrm{v})$ Triton $\mathrm{X}-100$ ] and cytochrome $c$ oxidase [in the presence of $0.002 \%(\mathrm{v} / \mathrm{v})$ Triton $\mathrm{X}-100$ ] activities were measured spectrophotometrically as described previously [17]. For each of the assayed activities, the distribution on the density gradient is reported as a Relative Specific Activity (RSA) profile. RSA was defined as (percentage of recovered activity in a fraction) $f$ (percentage of recovered protein in this fraction), with values measured in P3 taken as $100 \%$. Overall recovery values for each activity are given in the Figure legends.

\section{Measurement of $\mathrm{Ca}^{2+}$ uptake in permeabilized cells}

Chromaffin cells were isolated from bovine adrenal glands by the protocol of Burgoyne et al. [26]. The final suspension of cells in isolation buffer [Buffer 1; composed of (concentrations in $\mathrm{mM}$ ): Hepes, 25 (pH 7.4); $\mathrm{NaCl}, 145 ; \mathrm{KCl}, 5 ; \mathrm{NaH}_{2} \mathrm{PO}_{4}, 1.2$; glucose, 10] was washed in Buffer 1 containing $1 \mathrm{mM}$ EGTA, followed by two more washes in Buffer 1. Cells were then suspended (about 16 million cells $/ \mathrm{ml}, 20 \mathrm{ml} /$ vial) in Buffer 1 . Cells were kept at room temperature in a capped vial, and the $95 \% \mathrm{O}_{2} / 5 \% \mathrm{CO}_{2}$ mixture was passed through the suspension once every hour for $10 \mathrm{~min}$. This cell preparation yielded stable responses for up to $8 \mathrm{~h}$ after isolation. Prior to each assay run, $1 \mathrm{ml}$ of the cell suspension was withdrawn, centrifuged, and the cells were resuspended in $400 \mu \mathrm{l}$ of Buffer 2 [concentrations in mM: Hepes 25 (pH 7.2); KCl, $110 ; \mathrm{NaCl}, 10 ; \mathrm{KH}_{2} \mathrm{PO}_{4}, 2 ; \mathrm{MgCl}_{2}, 1 ; \mathrm{NaN}_{3}$, 10] at $37^{\circ} \mathrm{C}$. This suspension was transferred to a disposable semi-microcuvette (Brand, GFR) mounted in a Hitachi F2000 spectrofluorimeter and kept at $37^{\circ} \mathrm{C}$. In addition to the components of Buffer 2 and the cells, the final cuvette mixture (770 $\mu$ l) contained $6.5 \mathrm{mM} \mathrm{Na} \mathrm{P}_{2} \mathrm{O}_{7}, 27.6 \mathrm{mM}$ creatine phosphate, 44.7 units $/ \mathrm{ml}$ creatine kinase and $0.65 \mu \mathrm{M}$ fluo-3. To this mixture, $20 \mu \mathrm{l}$ of digitonin ( $1 \mathrm{mM}$ in Buffer 2) was added and, following $5 \mathrm{~min}$ incubation, $\mathrm{Ca}^{2+}$ uptake was started by adding $50 \mu \mathrm{l}$ of $16 \mathrm{mM}$ ATP. Stock solutions of thapsigargin $(1 \mathrm{mM}$ in DMSO), caffeine (50 mM in Buffer 2$)$ and $\operatorname{Ins} P_{3}(1 \mathrm{mM}$ in $25 \mathrm{mM}$ Hepes, $\mathrm{pH}$ 7.2) were used for subsequent additions. The fluo-3 fluorescence values were converted into free $\mathrm{Ca}^{2+}$ concentrations using the relationship $\left[\mathrm{Ca}^{2+}\right]_{\text {free }}=K_{\mathrm{d}}{ }^{*}\left[\left(F-F_{\min }\right) /\right.$ $\left(F_{\max .}-F\right)$ ] [8]. The $K_{\mathrm{d}}$ for fluo-3- $\mathrm{Ca}^{2+}$ complex under our conditions of temperature and ionic strength was $444 \mathrm{nM}$ (S.E.M. $20 \mathrm{nM}, n=3$ ), as determined at known free $\mathrm{Ca}^{2+}$ concentrations in EGTA buffers $[24,27]$. $F_{\max }$ and $F_{\min \text {. }}$ were determined at the end of each run following the additions of $\mathrm{Ca}^{2+}$ (final concentration $200 \mu \mathrm{M}$ ) and EGTA (final concentration $6.5 \mathrm{mM}$ ) respectively. When caffeine had been added in the course of a run, the $F_{\max }$ and $F_{\min }$. values were decreased due to combined effects of dilution and fluorescence quench. This fluorescence decrease $(15.6 \%$, S.E.M. $0.3 \%, n=5$; for each $100 \mu \mathrm{l}$ of $50 \mathrm{mM}$ caffeine added) was corrected for in the calculation of free $\mathrm{Ca}^{2+}$ values. The mean values reported are from measurements on cell batches from different experimental days.

\section{Other procedures and materials}

Protein was measured by the fluorescamine method [28]. Thapsigargin was a gift from Dr. S. B. Christensen. Fluo-3 (pentaammonium salt) was from Molecular Probes, U.S.A. All other materials were of the highest purity available from commercial sources.

\section{RESULTS}

Distribution of immunologically defined $\mathrm{Ca}^{2+}$-store proteins in adrenal medulla microsomal fractions: Ins $P_{3}$ receptor, ryanodine receptor and $\mathrm{Ca}^{2+}$-ATPases

Figure 1 shows a schematic representation of the banding pattern (i.e. subfractions collected) and the protein distribution following fractionation of adrenal medulla microsomes by centrifugation of the crude P3 membrane pellet on a discontinuous sucrose gradient. Two peaks of microsomal protein were observed to separate and these migrated to the $17 / 30 \%$ and the $30 / 50 \%$ sucrose interfaces, corresponding to membrane subfractions 4 and 6 respectively.

Following SDS/PAGE and protein transfer on to membranes, the gradient fractions were probed with antibodies raised against the Ins $P_{3}$ receptor (Figure $2 \mathrm{a}$ ), ryanodine receptor (Figure $2 \mathrm{~b}$ ) or skeletal muscle $\mathrm{Ca}^{2+}$-ATPase [20] (Figure 2c). With each of the antibodies, specific immunostaining was obtained in the highsucrose portion of the gradient (fractions 6, 7 and 8). The Ins $P_{3}$ receptor and ryanodine-receptor immunoreactivity peaked in fractions $6(30 \% / 50 \%$ sucrose interface) and $7(50 \%$ sucrose), while $\mathrm{Ca}^{2+}$-ATPase immunoreactivity was evenly distributed through fractions 6,7 and 8 (fraction 8 representing the material pelleted through $50 \%$ sucrose). The Ins $P_{3}$-receptor-immunoreactive band in adrenal medulla membranes displayed a relative molecular mass of $\sim 260 \mathrm{kDa}$ that was identical to the relative mobility of the Ins $P_{3}$ receptor in the lane containing brain microsomes (Figure 2a). An identical specific immunostaining pattern was obtained with rabbit polyclonal (Figure 2a) and rat monoclonal (results not shown) antibodies against $\operatorname{Ins} P_{3}$ receptor. Interestingly, a faint lower band of $\sim 180 \mathrm{kDa}$ was also observed only in adrenal medulla membranes. This $\sim 180 \mathrm{kDa}$ immunoreactive band may represent a proteolytic product of the

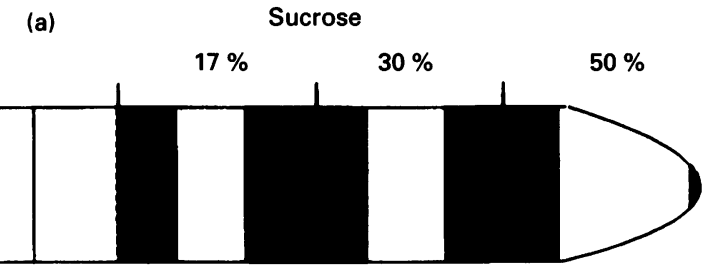

(b)

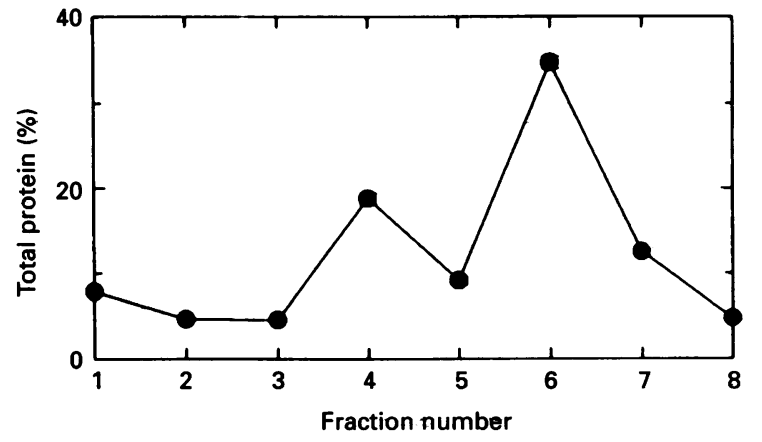

Figure 1 Discontinuous sucrose gradient used for subfractionation of bovine adrenal medulla microsomes

(a) The interfaces and sucrose content of each $10 \mathrm{ml}$ layer are indicated. The fractions are indicated as black and white bands. (Fraction 1 corresponds to the volume of total microsomes applied to the gradient). (b) Distribution of the protein. Values (S.E.M. values are smaller than symbols) are percentages of the total amount applied to the gradient. Mean overall recovery was $97.4 \%$, S.E.M. $1.5 \% ; n=11$. 
(a)

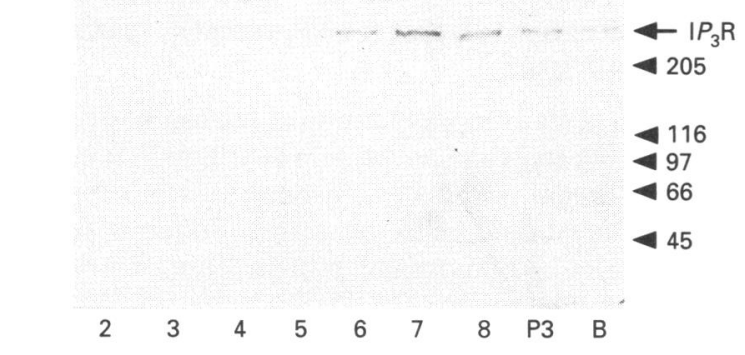

(b)

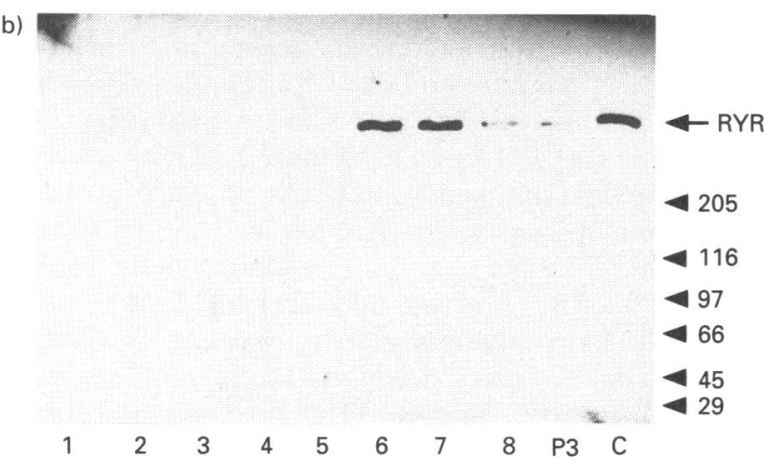

(c)

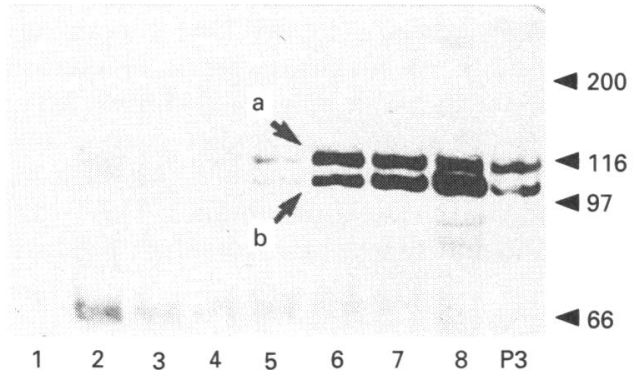

Figure 2 Immunolocalization of the Ins $P_{3}$ receptor, ryanodine receptor and ER $\mathrm{Ca}^{2+}$-ATPases in the density-gradient fractions from adrenal medulla microsomes

Fraction numbers are indicated underneath each blot. P3 denotes total microsomes. Positions of molecular-mass markers are indicated by arrowheads, with values in $\mathrm{kDa}$. (a) Immunostaining using rabbit antisera to the mammalian Ins $P_{3}$ receptor. (Essentially identical distribution of specific staining was obtained using rat monoclonal antibody $4 \mathrm{C} 11$ against Ins $P_{3}$ receptor.) $\mathrm{B}$, rabbit brain microsomes. (b) Immunostaining using rabbit antisera to the mammalian ryanodine receptor. C: rabbit heart muscle microsomes. (c) Immunostaining using Y/1F4 monoclonal antibody against skeletal muscle $\mathrm{Ca}^{2+}$-ATPase. Arrows $\mathbf{a}$ and $\mathbf{b}$ mark specifically immunostained proteins. [Data in (a), (b) and (c) each represent 3-4 independent microsome preparations].

$\sim 260 \mathrm{kDa}$ protein, as a partial proteolysis product of $\operatorname{Ins} P_{3}$ receptor of $\sim 200 \mathrm{kDa}$ has been described [29]. Immunostaining with the ryanodine-receptor antibody also revealed a highmolecular-mass protein band in adrenal medulla membranes that displayed an identical mobility to the cardiac muscle ryanodine receptor (Figure $2 \mathrm{~b}$ ). The molecular mass of the ryanodine receptor deduced from cDNA sequencing analysis is $\sim 560 \mathrm{kDa}[30]$.

The two bands recognized by the monoclonal antibody against the skeletal muscle $\mathrm{Ca}^{2+}$-ATPase $(116$ and $100 \mathrm{kDa}$, designated a and $\mathbf{b}$, respectively, in Figure 2c) were always distributed in parallel and with similar intensity. Since equal amounts of adrenal medulla microsomal protein were run on all gel lanes within each blot, the distribution of immunostaining intensity largely reflects the distribution profiles of each of the studied proteins. Owing to the non-linear nature of several steps in the immunodetection procedure, such staining profiles present a semi-quantitative, rather than a precise quantitative measure of true antigen distribution. However, the quantitative aspect of immunostaining in Figures 2 and 3(b) is readily apparent. Thus, the staining intensity in the starting fraction (P3) was always found to be intermediate between those fractions with the strongest, and those with the weakest staining.

\section{The thapsigargin-sensitive and thapsigargin-insensitive $\mathrm{Ca}^{2+}$ uptake in the microsomal fractions}

The distribution of the major $\mathrm{Ca}^{2+}$-store marker proteins (Ins $P_{3}$ and ryanodine receptors and $\mathrm{Ca}^{2+}$-ATPases) suggested that vesicles derived from $\mathrm{Ca}^{2+}$ stores were mainly found to sediment at, or below, the $30 \% / 50 \%$ sucrose interface. Since chromaffin cells were postulated to possess both thapsigargin-sensitive and thapsigargin-insensitive $\mathrm{Ca}^{2+}$-store pumps (see Introduction and Discussion sections), it was of interest to compare the distribution of $\mathrm{Ca}^{2+}$-store proteins with that of the thapsigargin-sensitive and thapsigargin-insensitive components of ATP-dependent ${ }^{45} \mathrm{Ca}^{2+}$ uptake (' $\mathrm{Ca}^{2+}$ uptake'). In contrast to the high background rendering accurate measurements of the $\mathrm{Ca}^{2+}$-dependent ATPase activity impractical (see below), the ATP-independent ${ }^{45} \mathrm{Ca}^{2+}$ binding to the vesicles was very low $(5-10 \%$ of the total ATPdependent uptake). $\mathrm{Ca}^{2+}$ uptake was measured across the gradient in the absence and presence of $100 \mathrm{nM}$ thapsigargin, a concentration found to be supramaximal in our earlier work [17]. Distribution profiles of the thapsigargin-insensitive and thapsigargin-sensitive components of $\mathrm{Ca}^{2+}$ uptake were clearly different, as shown in Figures 3(a) and 3(d). While the thapsigargininsensitive $\mathrm{Ca}^{2+}$ uptake peaked in fraction 5 (Figure 3a), the thapsigargin-sensitive component had a broad distribution, with a slight peak in fraction 3 followed by a slow decline towards fractions 7 and 8 (Figure $3 \mathrm{~d}$ ).

\section{$\mathrm{Ca}^{2+}$-dependent ATPase activity in the adrenal medulla microsomes}

In addition to $\mathrm{Ca}^{2+}$ uptake, it was of considerable interest to examine the gradient distribution of $\mathrm{Ca}^{2+}$-ATPase activity, and in particular of its thapsigargin-sensitive and -insensitive components. However, due to the presence of a very high background level of $\mathrm{Ca}^{2+}$-independent ATP hydrolysis (Figure 4a), these experiments did not produce a reliable distribution profile. The $\mathrm{Ca}^{2+}$-dependent and $\mathrm{Ca}^{2+}$-independent (background) ATPase activities in the total microsomal fraction are illustrated in Figure 4(a). The $\mathrm{Ca}^{2+}$-independent background was 90 and $83 \%$ respectively, in the absence and presence of $\mathrm{Ca}^{2+}$ ionophore A23187 $(1 \mu \mathrm{M})$. In the presence of the non-ionic detergent dodecyl octaoxyethyleneglycol $\left(\mathrm{C}_{12} \mathrm{E}_{8}, 0.2 \mathrm{mg} / \mathrm{ml}\right)$, the $\mathrm{Ca}^{2+}$ dependent ATPase activity was increased 3.8 -fold $(P<0.02$, $n=4)$ and the background decreased to $63 \%$. Inhibition by thapsigargin $(100 \mathrm{nM})$ of $\mathrm{Ca}^{2+}$-ATPase activity was found to be statistically significant $(P<0.02, n=4)$ only when measured in the presence of A23187. This lack of clear inhibition by thapsigargin in all cases in adrenal medulla microsomes was not due to problems inherent in our assay: when a preparation of rabbit skeletal muscle sarcoplasmic reticulum was tested in parallel with adrenal medulla P3 fraction, thapsigargin abolished completely the activity of sarcoplasmic reticulum $\mathrm{Ca}^{2+}$-ATPase under all tested conditions (Figure 4b), as expected based on earlier studies in this system $[13,14]$. 


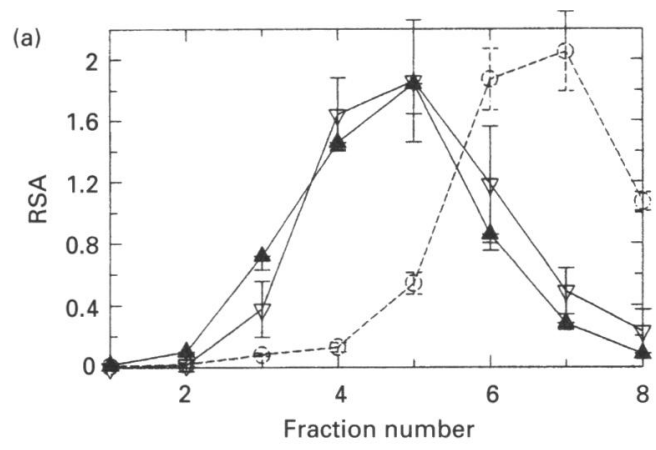

(b)

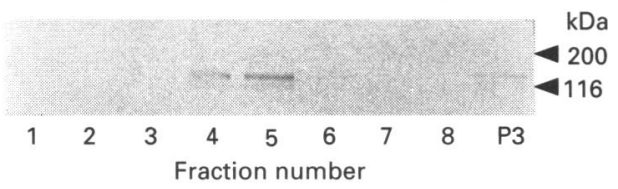

(c)

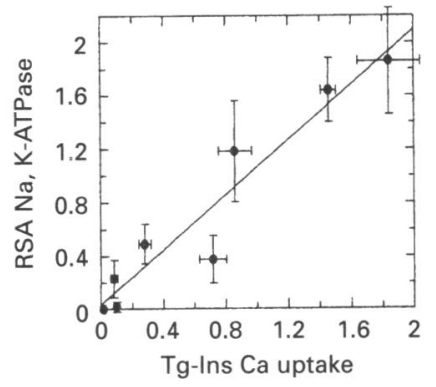

RSA

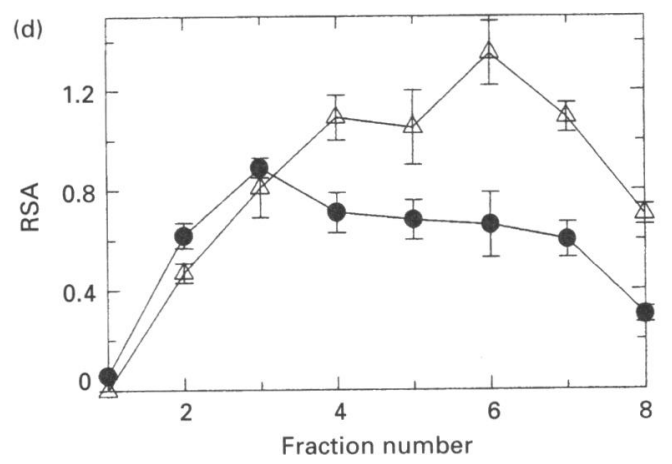

Figure 3 Distribution of the ATP-dependent $\mathrm{Ca}^{2+}$ uptake and subcellular markers in the density-gradient fractions from adrenal medulla microsomes

RSA is defined in the Materials and methods section. (a) and (d): For each activity, $n$ is the total number of gradients from 3-6 different batches of adrenals; $R$ ( \pm S.E.M.) is the mean total activity recovered as a percentage of the activity loaded. (a) Distribution of the thapsigargininsensitive component of $\mathrm{Ca}^{2+}$ uptake $(\boldsymbol{\Delta} ; n=4, \mathrm{R}=96.2 \pm 1.6)$, the ouabain-sensitive $\mathrm{Na}^{+}, \mathrm{K}^{+}$-ATPase $(\nabla ; n=7, \mathrm{R}=100.4 \pm 0.7)$ and cytochrome $c$ oxidase $(\mathrm{O} ; n=3, \mathrm{R}=$ $101.4 \pm 9.8$ ). (b) Distribution of the immunostaining obtained using MA3-914 monoclonal antibody against plasma membrane $\mathrm{Ca}^{2+}$-ATPase. (C) Plot of the RSA of ouabain-sensitive $\mathrm{Na}^{+}, \mathrm{K}^{+}$-ATPase against RSA of thapsigargin-insensitive $\mathrm{Ca}^{2+}$ uptake in corresponding fractions. The linear regression line was significant with $P=0.0002$. (d) Distribution of the thapsigarginsensitive component of $\mathrm{Ca}^{2+}$ uptake $(O ; n=4, \mathrm{R}=61.7 \pm 2.3$ ) and NADPH-cytochrome $c$ oxidoreductase $(\triangle ; n=3, \mathrm{R}=99.1 \pm 6.6)$.

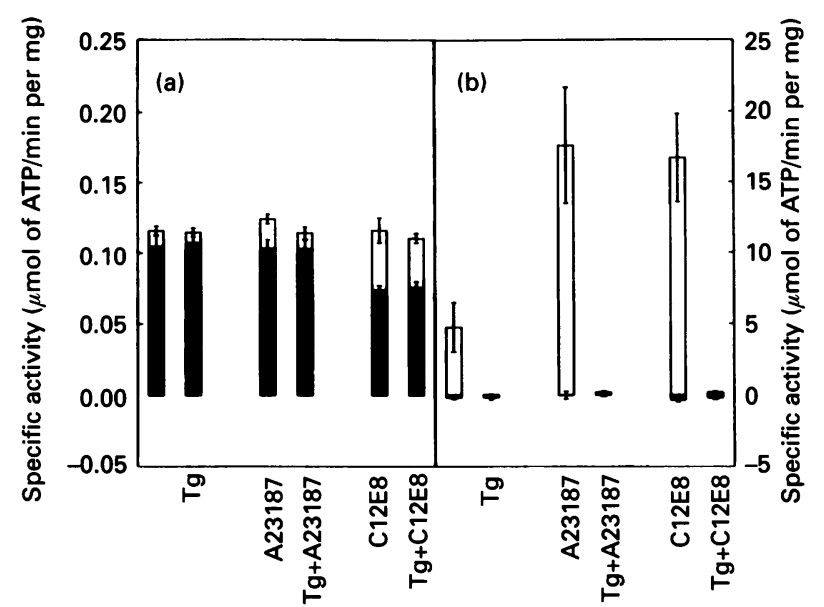

Figure 4 Comparison of $\mathrm{Ca}^{2+}$-ATPase activities in adrenal medulla microsomes (a) and sarcoplasmic reticulum (b)

For each condition, total (in the presence of $50 \mu \mathrm{M} \mathrm{Ca}{ }^{2+}$ ) and background (in the presence of $4 \mathrm{mM}$ EGTA) rates of ATP hydrolysis are shown, with the $\mathrm{Ca}^{2+}$-dependent ATPase activity corresponding to the clear segment of each column. When present, additions to the assay of various agents are indicated by the following abbreviations: Tg, thapsigargin $(100 \mathrm{nM})$; A23187, $\mathrm{Ca}^{2+}$ ionophore $(1 \mu \mathrm{M}) ; \mathrm{C}_{12} \mathrm{E}_{8}(0.2 \mathrm{mg} / \mathrm{ml})(\mathbf{a})$ or $(0.01 \mathrm{mg} / \mathrm{ml})$ (b). (a) Means from four independent preparations; S.E.M. values are indicated by bars. (b) Means from two independent preparations; ranges are indicated by bars.

Relationship between the distribution of the thapsigargin-sensitive and thapsigargin-insensitive components of $\mathrm{Ca}^{2+}$ uptake, and that of markers for plasma membranes, ER and mitochondria

Subcellular fractions from bovine adrenal medulla contain insideout plasma membrane vesicles [31]. The ATP-dependent $\mathrm{Ca}^{2+}$ uptake to these vesicles is due to the presence of the plasma membrane $\mathrm{Ca}^{2+}$ pump of the PMCA (Plasma Membrane $\mathrm{Ca}^{2+}$ ATPase) family [32], which is not inhibited by thapsigargin [13]. We therefore compared the gradient distribution of the thapsigargin-insensitive component of $\mathrm{Ca}^{2+}$ uptake with that of plasma membranes, as defined by the ouabain-sensitive $\mathrm{Na}^{+}, \mathrm{K}^{+}$-ATPase, a specific plasma membrane marker [33]. As shown in Figures $3(\mathrm{a})$ and $3(\mathrm{c})$, a strong statistical correlation $(P=0.0002)$ was found between the distribution profiles of these two activities.

To test further this co-distribution of the thapsigargin-insensitive component of $\mathrm{Ca}^{2+}$ uptake and plasma membranes, we probed the blots of gradient fractions with a monoclonal antibody against plasma membrane $\mathrm{Ca}^{2+}$ pump (PMCA). A PMCA-like immunoreactive band was found with molecular mass of $140 \mathrm{kDa}$ and staining intensity peaking in fractions 4 and 5 (Figure 3b). In addition to this major band, a minor component (approximately $120 \mathrm{kDa}$ ) appeared to co-migrate with the major band. A proteolysis product of plasma membrane $\mathrm{Ca}^{2+}$ pump with molecular mass of approximately $124 \mathrm{kDa}$ has been described, reflecting a calpain-mediated cleavage of the $\mathrm{C}$-terminal domain of the pump [32].

The SERCA family $\mathrm{Ca}^{2+}$-ATPases are thought to be localized in the ER [4] and related structures, including calciosomes, organelles postulated to be particularly specialized for $\mathrm{Ca}^{2+}$ storage [3,34]. NADPH-cytochrome $c$ oxidoreductase, a marker for ER [35], was found to distribute broadly across the gradient, with a peak RSA centred at fraction 6 . This distribution was somewhat different from, albeit broadly overlapping with, that of the thapsigargin-sensitive $\mathrm{Ca}^{2+}$ uptake (Figure 3d). Importantly, both of these distribution profiles were in sharp contrast to 


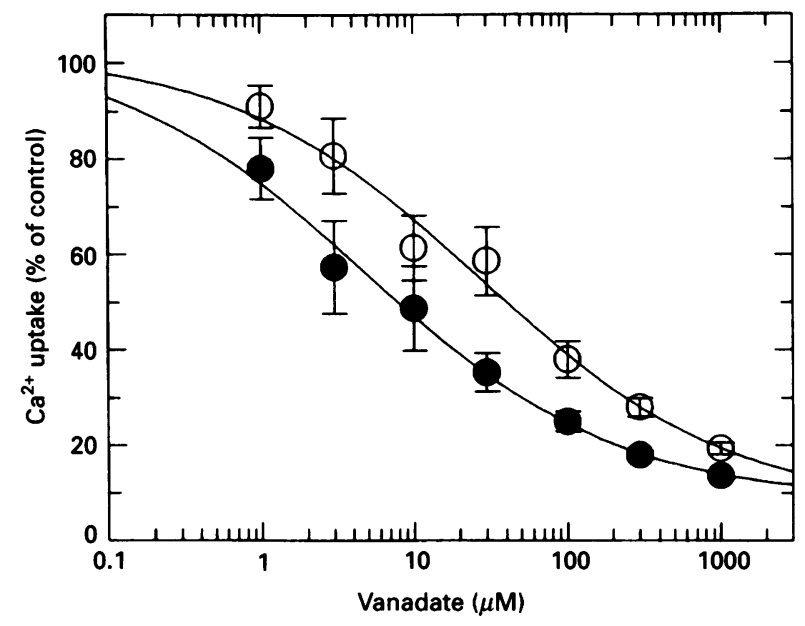

Figure 5 Inhibition by vanadate of the thapsigargin-sensittve and thapsigargin-insensitive components of $\mathrm{Ca}^{2+}$ uptake

For the thapsigargin-sensitive $\mathrm{Ca}^{2+}$ component $(\mathrm{O} ; n=3)$, the difference between $\mathrm{Ca}^{2+}$ uptake in the absence and presence of thapsigargin was measured (fraction 2). For the thapsigargin-insensitive component $\left(O_{n=3}\right), \mathrm{Ca}^{2+}$ uptake in the presence of thapsigargin was measured (fraction 5). Error bars indicate S.E.M. values.

the thapsigargin-insensitive component of $\mathrm{Ca}^{2+}$ uptake and $\mathrm{Na}^{+}, \mathrm{K}^{+}$-ATPase (Figure $3 \mathrm{a}$ versus $3 \mathrm{~d}$ ), as well as to the PMCAlike immunoreactivity (Figure $3 \mathrm{~b}$ versus $3 \mathrm{~d}$ ).

Vesicles derived from mitochondria are able to accumulate $\mathrm{Ca}^{2+}$ in an ATP-dependent manner, utilizing the inside-negative potential arising from $\mathrm{H}^{+}$transport across the inner membranes by the $F_{1} F_{0}$-type ATPase [36]. This mitochondrial transport displays low affinity for $\mathrm{Ca}^{2+}$ and becomes negligible below $100 \mathrm{nM}$ free $\mathrm{Ca}^{2+}$ [37]. To ensure that the measured uptake of ${ }^{45} \mathrm{Ca}^{2+}$ was to the non-mitochondrial $\mathrm{Ca}^{2+}$ stores, all the uptake measurements were done at $50 \mathrm{nM}$ free $\mathrm{Ca}^{2+}$. As a further precaution, we measured the distribution of cytochrome $c$ oxidase, a marker for inner mitochondrial membranes [38]. It is clear from Figures 3(a) and 3(d), that this distribution clearly differed from the profiles exhibited by both thapsigargin-insensitive and thapsigargin-sensitive components of $\mathrm{Ca}^{2+}$ uptake.

\section{Inhibition by vanadate of the thapsigargin-insensitive and thapsigargin-sensitive components of $\mathrm{Ca}^{2+}$ uptake in microsomal fractions}

$\mathrm{Ca}^{2+}$-ATPases of the ER (SERCA type), as well as the $\mathrm{Ca}^{2+}$ pumping ATPases of plasma membranes (PMCA type), are susceptible to inhibition by vanadate, a general inhibitor of $P$ type ATPases [32]. In a number of studies vanadate was found to act as a more potent inhibitor of the PMCA class than of the SERCA class of $\mathrm{Ca}^{2+}$ pumps, thus furnishing another pharmacological criterion (in addition to thapsigargin) to differentiate between the two ATPase families (see [32,39-41] for plasma membrane; $[25,42]$ for ER ATPases). To see whether the differences in thapsigargin sensitivity of $\mathrm{Ca}^{2+}$ uptake between the microsomal fractions were paralleled by differences in their sensitivity to vanadate, we have determined the potency of $\mathrm{Ca}^{2+}$ uptake inhibition by vanadate in two selected fractions. The two fractions were chosen for their widely different thapsigargin sensitivities: fraction 5, containing the peak of the thapsigargininsensitive component of $\mathrm{Ca}^{2+}$ uptake, and fraction 2 , where the thapsigargin-sensitive component of $\mathrm{Ca}^{2+}$ uptake comprised up to $90 \%$ of the total uptake. (Fraction 2 corresponded to the thapsigargin-sensitive light microsomal fraction described in [17].) The $\mathrm{IC}_{50}$ values for vanadate inhibition were $12.0 \mu \mathrm{M}$ (S.E.M. 2.5, $n=3$ ) in fraction 5, and $57.3 \mu \mathrm{M}$ (S.E.M. 9.4, $n=3$ ) in fraction 2 (Figure 5).

\section{Inhibition by thapsigargin of $\mathrm{Ca}^{2+}$ uptake to Ins $P_{3}$-sensitive and caffeine-sensitive stores in permeabillized cells}

The co-migration on the density gradient of immunologically detected receptors for Ins $P_{3}$ and ryanodine with SERCA Ca ${ }^{2+}$ ATPase-like immunoreactive proteins suggested that $\mathrm{Ca}^{2+}$ loading of both the Ins $P_{3}$-sensitive and ryanodine-sensitive stores might be carried out by SERCA-type, thapsigargin-sensitive $\mathrm{Ca}^{2+}$-ATPases. To test this possibility by an independent approach we carried out the experiments on isolated permeabilized cells. Figure 6 shows that addition of ATP [clear arrowheads in (a),(c),(d)] to digitonin-permeabilized cells initiated the uptake of $\mathrm{Ca}^{2+}$, as measured by a decrease in fluo-3 fluorescence in the extracellular medium. Typical values of free $\mathrm{Ca}^{2+}$ immediately following ATP addition were between 500 and $800 \mathrm{nM}$. These values were in part determined by the presence of pyrophosphate $(5.8 \mathrm{mM})$ in the medium, which was included to increase the loading capacity of $\mathrm{Ca}^{2+}$ stores [8,43]. (In trial experiments in the absence of pyrophosphate, the corresponding initial $\mathrm{Ca}^{2+}$ concentrations were between 4 and $9 \mu \mathrm{M}$.) However, pyrophosphate also acted to buffer the changes in medium free $\mathrm{Ca}^{2+}$ concentration. The extent of this buffering is illustrated in Figure 6(a). In the middle and bottom traces, at each black arrowhead $10 \mathrm{nmol}$ of $\mathrm{Ca}^{2+}$ were added, each addition raising the total $\mathrm{Ca}^{2+}$ concentration by 11.5 to $11.8 \mu \mathrm{M}$. The corresponding increases of free $\mathrm{Ca}^{2+}$ were, successively, 306 and $322 \mathrm{nM}$ (middle trace) and 426, 543 and $470 \mathrm{nM}$ (bottom trace). This strong dampening of the free $\mathrm{Ca}^{2+}$ changes was not due to an initial very rapid uptake of $\mathrm{Ca}^{2+}$ by the cells, since similar percentage change in free $\mathrm{Ca}^{2+}$ relative to the added total $\mathrm{Ca}^{2+}$ was observed in test runs with no cells present $(3.5 \%$, S.E.M. $0.6 \%, n=4)$.

Following the uptake phase, in routine runs (without $\mathrm{Ca}^{2+}$ additions; Figure 6a, upper trace) a plateau was reached at a mean free $\mathrm{Ca}^{2+}$ concentration of $54.6 \mathrm{nM}$ (S.E.M. $5.1 \mathrm{nM}$, $n=3$ ). Addition of $\operatorname{Ins} P_{3}$ (final $11.6 \mu \mathrm{M}$ ) caused $\mathrm{Ca}^{2+}$ release, increasing free $\mathrm{Ca}^{2+}$ concentration by about $43 \%$ over the plateau value (mean increase $23.4 \mathrm{nM}$, S.E.M. 3.6, $n=3$ ). Routine control additions of $10 \mu \mathrm{l}$ of $25 \mathrm{mM}$ Hepes, pH 7.2, 1-2 min before Ins $P_{3}$ never caused any measurable $\mathrm{Ca}^{2+}$ concentration change. Figure 6(b) demonstrates that the amplitude of the Ins $P_{3}$-induced $\mathrm{Ca}^{2+}$ release increased when previous additions of $\mathrm{Ca}^{2+}$ caused more $\mathrm{Ca}^{2+}$ to be sequestered in the stores. Between 6 and $8 \mathrm{~min}$ after the $\operatorname{Ins} P_{3}$, addition of caffeine (final concentration $5.2 \mathrm{mM}$ ) caused a fast increase in free $\mathrm{Ca}^{2+}$, followed by reuptake. Another caffeine addition evoked another release event (Figures $6 \mathrm{a}$ and $6 \mathrm{~b}$, all traces), followed by reuptake. The maximal release amplitudes following the first and second caffeine additions were, respectively, $37.1 \mathrm{nM}$ (S.E.M. $11.3 \mathrm{nM}$, $n=3$ ) and $12.2 \mathrm{nM}$ (S.E.M. $3.9 \mathrm{nM}, n=3$ ). The amplitudes of caffeine responses did not appear to change as a function of the amount of $\mathrm{Ca}^{2+}$ previously sequestered by the cells (Figure $6 \mathrm{~b}$ ). Since the employed doses of caffeine were submaximal, this observation may be explained by a quantal nature of $\mathrm{Ca}^{2+}$ release from the ryanodine-sensitive stores in response to caffeine, recently demonstrated by Cheek et al. [44].

When thapsigargin ( $94 \mathrm{nM}$ final concentration) was added during a period of reuptake after the second caffeine-induced $\mathrm{Ca}^{2+}$ release, an increase in free $\mathrm{Ca}^{2+}$ was always initiated (Figures 6a and 6b). In order to determine whether any portion 

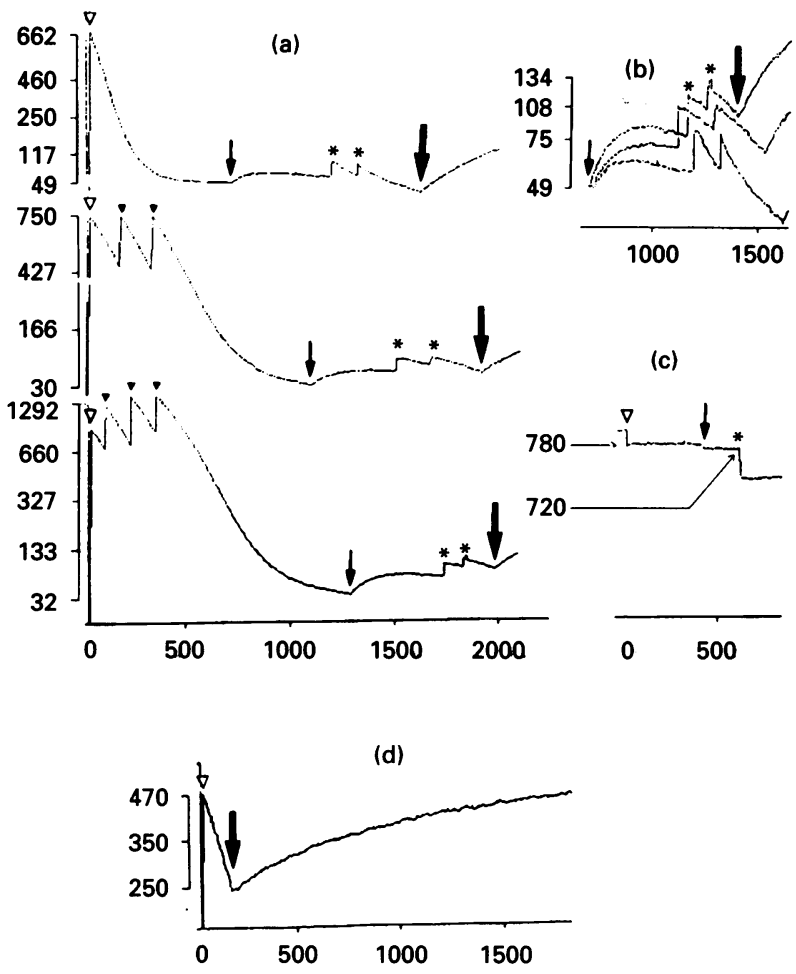

Figure 6 Inhibition by thapsigargin in isolated permeabilized chromaffin cells of $\mathrm{Ca}^{2+}$ uptake to Ins $P_{3}$-sensitive and caffeine-sensitive $\mathrm{Ca}^{2+}$ stores

Time course of fluo-3 fluorescence changes is shown under various conditions. In all records, time scale is in seconds, and free $\mathrm{Ca}^{2+}$ concentrations are in $\mathrm{nM}$. Symbols indicate various additions: ATP, clear arrowheads; $\mathrm{Ca}^{2+}$, black arrowheads; Ins $P_{3}$, Small arrows; caffeine, asterisks; thapsigargin, large arrows. (a) Permeabilized cells show the ATP-dependent uptake of $\mathrm{Ca}^{2+}$ and subsequent $\mathrm{Ca}^{2+}$ release in response to $\operatorname{Ins} P_{3}(11.6 \mu \mathrm{M})$, caffeine $(5.2 \mathrm{mM})$ and thapsigargin $(94 \mathrm{nM})$. Runs without (upper trace) or with (middle and bottom traces) $\mathrm{Ca}^{2+}$ additions ( $10 \mathrm{nmol}$ of $\mathrm{Ca}^{2+}$ for each pulse) are shown. (b) The amplitude of Ins $P_{3}$-evoked $\mathrm{Ca}^{2+}$ release is dependent on the amount of $\mathrm{Ca}^{2+}$ previously sequestered in the stores. Sections of the bottom, midale and top traces from part (a) are shown on an expanded $\mathrm{Ca}^{2+}$ concentrations scale, and are represented in (b) as top, middle and bottom traces, respectively. The onset points of the $\operatorname{Ins} P_{3}$-induced $\mathrm{Ca}^{2+}$ release were adjusted to a common origin. (For clarity, the additions of Ins $P_{3}$, cafteine and thapsigargin are indicated for the upper trace only). (c) Addition of ATP after thapsigargin fails to initiate the ATP-dependent $\mathrm{Ca}^{2+}$ uptake and subsequent additions of Ins $P_{3}$ and caffeine fail to evoke $\mathrm{Ca}^{2+}$ release. Free $\mathrm{Ca}^{2+}$ concentrations at the point of ATP and caffeine additions are indicated. (Each of these two additions caused a fluorescence drop due to combined effects of dilution and quench.) (d) Addition of thapsigargin (94 nM) during the net uptake phase of the ATP-dependent store loading arrests this loading, and releases quantitatively the amount of $\mathrm{Ca}^{2+}$ taken up through a slow leak. The data in (a) (upper trace), (b) (bottom trace), (c) and (d) each were obtained on 3-4 independent cell preparations. The data in (a) (middle and bottom traces) and (b) (middle and top traces) represent one cell preparation.

of the ATP-dependent $\mathrm{Ca}^{2+}$ uptake to the stores was resistant to thapsigargin inhibition, two types of experiments were carried out. In experiments illustrated in Figure 6(c), thapsigargin (125 nM final concentration) was added to the cells at the onset of incubation with digitonin, i.e. 5 min before ATP. Under these conditions, the level of $\mathrm{Ca}^{2+}$ following ATP addition remained either constant or declined slightly (e.g. 780 to $720 \mathrm{nM}$ in Figure 6c). Addition of Ins $P_{3}(11.6 \mu \mathrm{M}) 6 \mathrm{~min}$ after ATP (a time point when uptake is complete in Figure $6 \mathrm{a})$, and of caffeine $(5.2 \mathrm{mM})$ 9 min after ATP, failed to induce release. Addition of caffeine resulted in a $13 \%$ decrease in fluorescence, due to combined effects of dilution and a caffeine-induced fluorescence quench. In other runs we determined that the slight decline in $\mathrm{Ca}^{2+}$ level (e.g. $60 \mathrm{nM}$ over $9 \mathrm{~min}$ in Figure 6c) observed under these conditions was not affected by the presence of $\mathrm{Ca}^{2+}$ ionophore $\mathrm{A} 23187$ (100 $\mathrm{nM})$, a concentration causing a rapid release of $\mathrm{Ca}^{2+}$ from the stores (results not shown).

In the second type of experiments (illustrated in Figure 6d), thapsigargin (125 $\mathrm{nM}$ final concentration) was added before the uptake phase was expected to level off. This addition caused the uptake to be arrested and replaced by a long-lasting $\mathrm{Ca}^{2+}$ release, with $\mathrm{Ca}^{2+}$ returning to the starting level after about $30 \mathrm{~min}$. Thus, no amount of $\mathrm{Ca}^{2+}$ was removed from the medium by an ATP-dependent pump insensitive to thapsigargin inhibition under these conditions.

\section{DISCUSSION}

This work has addressed two interrelated aspects of the biochemistry of non-mitochondrial $\mathrm{Ca}^{2+}$ stores in adrenal medulla chromaffin cells. First, we examined the distribution profile of the Ins $P_{3}$-sensitive and the ryanodine-sensitive $\mathrm{Ca}^{2+}$ stores upon microsomal subfractionation on density gradients. To our knowledge, such a subcellular fractionation approach with simultaneous monitoring of $\mathrm{Ca}^{2+}$-channel and $\mathrm{Ca}^{2+}$-pump proteins and combining immunological with functional data has up to now only been limited to microsomal fractions from cerebellum [45-47]. Secondly, the distribution pattern of $\mathrm{Ca}^{2+}$-store marker proteins in subcellular fractions was used together with measurements on isolated permeabilized cells to ascertain the thapsigargin sensitivity and probable nature of $\mathrm{Ca}^{2+}$ pumps responsible for the ATP-dependent $\mathrm{Ca}^{2+}$ uptake to Ins $P_{3}-$ and ryanodinesensitive stores in chromaffin cells.

\section{Localization of the key $\mathrm{Ca}^{2+}$-store proteins in submicrosomal fractions}

The location of Ins $P_{3}$ and ryanodine receptors, as well as $\mathrm{Ca}^{2+}$ ATPases on the gradient was probed immunologically (Figures 2 and $3 \mathrm{~b}$ ). The specificity of the monoclonal antibody raised against the $\mathrm{Ca}^{2+}$-ATPase has previously been characterized $[20,48]$. The specificity of the $\operatorname{Ins} P_{3}$ receptor and ryanodine receptor antibodies was apparent from the identical mobility of the immunoreactive band in adrenal medulla microsomes with that observed for the $\operatorname{Ins} P_{3}$ receptor and ryanodine receptor in brain $(\sim 260 \mathrm{kDa})$ and heart muscle $(\sim 560 \mathrm{kDa})$ microsomes, respectively (Figures $2 \mathrm{a}$ and $2 \mathrm{~b}$ ). These considerations strongly indicate that the detected immunopositive bands do in fact represent the respective $\mathrm{Ca}^{2+}$-store proteins.

Both Ins $P_{3}-$ and ryanodine-receptors and $\mathrm{Ca}^{2+}$-ATPases were found enriched in the heavy portion of the gradient, i.e. at the $30 \% / 50 \%$ sucrose interface or below. Fraction 6 , comprising $30 \% / 50 \%$ sucrose interface, contained about $35 \%$ of the total applied protein, as well as a strong enrichment in the Ins $P_{3}$ - and ryanodine-receptors and $\mathrm{Ca}^{2+}$-ATPases. This fraction showed also the maximal concentration of the ER marker enzyme (NADPH-cytochrome $c$ oxidoreductase, [35]), while the specific activities of the plasma membrane marker and the thapsigargininsensitive component of $\mathrm{Ca}^{2+}$ uptake were diminished to about $50 \%$ of their peak values in fraction 5 . Therefore, the material collected at $30 \% / 50 \%$ sucrose interface would appear to be especially interesting for any further attempts to fractionate $\mathrm{Ca}^{2+}$ stores in adrenal medulla.

\section{Relationship between the distribution of SERCA-type ATPases as determined by immunostaining, and by thapsigargin-sensitive $\mathrm{Ca}^{2+}$ uptake}

The monoclonal antibody Y/1F4 (raised against skeletal muscle sarcoplasmic reticulum $\mathrm{Ca}^{2+}$-ATPase [20]) recognizes the amino 
acid sequence Asn-Lys-Met-Phe-Val-Lys [48]. This sequence is present in all subtypes of SERCA ATPases except in SERCA 3, where serine is substituted for asparagine [4]. The molecular mass values of 116 and $100 \mathrm{kDa}$ for the two Y/1F4-immunoreactive bands (Figure $2 \mathrm{c}$ ) are within the range compatible with the predicted sizes of SERCA $2 b$ and SERCA 3 isoenzymes (114.6 and $109.5 \mathrm{kDa}$ respectively [42]). While SERCA 1 and SERCA 2a forms are restricted to muscle, SERCA $2 b$ and 3 are widely distributed [4]. Little information is so far available about the expression of these ATPases in neural or neuroendocrine tissues, with the exception of the brain, where both SERCA $2 b$ and SERCA 3 forms have been found [49,50]. The functional differences between the individual SERCA ATPases are not well understood, but appear to include $\mathrm{Ca}^{2+}$ affinity about 3-fold lower for SERCA 3, as compared with SERCA 1, 2a and 2b isoenzymes [42]. It will be interesting to see whether the two $\mathrm{Ca}^{2+}$-ATPases are expressed within the same, or different, populations of chromaffin cells.

A distinguishing property of all SERCA ATPases is their high sensitivity to inhibition by thapsigargin [13,51]. The thapsigarginsensitive $\mathrm{Ca}^{2+}$ uptake presented a broad distribution profile on the sucrose gradient (Figure 3d). This profile appears to differ from the distribution of the putative SERCA enzymes as determined by immunostaining (Figure 2c). The difference is particularly striking regarding fractions $2,3,4$ and 5 , in which the RSA values of the thapsigargin-sensitive $\mathrm{Ca}^{2+}$ uptake do not show the same sharp decline as observed for the SERCA-like proteins by immunostaining. This discrepancy might lead one to suggest a presence in fractions 2-5 of a thapsigargin-sensitive $\mathrm{Ca}^{2+}$-ATPase lacking the epitope recognized by the $\mathrm{Y} / 1 \mathrm{~F} 4$ antibody. However, caution is warranted regarding such a conclusion given the fact that the thapsigargin-sensitive $\mathrm{Ca}^{2+}$ uptake was precisely the only type of activity for which the recovery following the gradient centrifugation was incomplete by $38 \%$. In contrast, the recoveries of all the other activities (in particular, including the thapsigargin-insensitive $\mathrm{Ca}^{2+}$ uptake) were essentially quantitative (see values in Figure 3, legend). The reasons for this significant and selective loss of the thapsigarginsensitive component of $\mathrm{Ca}^{2+}$ uptake remain obscure at present. However, to the extent that this loss occurred preferentially from those fractions showing immunostaining for the ER-type $\mathrm{Ca}^{2+}$ ATPases (i.e. 6-8), it would account at least in part for the apparent discrepancy between the functional and immunological data. Indeed, high RSA values in fractions 6 and 7 of the ER marker (NADPH-cytochrome $c$ oxidoreductase, Figure 3d) are consistent with this gradient region being a preferential locus for ER-associated $\mathrm{Ca}^{2+}$-pumps.

Our attempt to assess the distribution of the thapsigarginsensitive and thapsigargin-insensitive $\mathrm{Ca}^{2+}$-ATPases by measurements of ATP hydrolysis was frustrated by very high levels of background activity $\left(\mathrm{Ca}^{2+}\right.$-independent activity) (83 to $90 \%$ ). Since measurement of the 'specific', $\mathrm{Ca}^{2+}$-dependent ATP hydrolysis involves taking a difference between the total activity in the presence of $\mathrm{Ca}^{2+}$ and this background, the experimental error due to the large background values constituted a major portion $(30-90 \%)$ of the 'specific' activity (Figure 4a). In the total microsomes, a statistically significant inhibition by $100 \mathrm{nM}$ thapsigargin of the $\mathrm{Ca}^{2+}$-dependent component was only found in the presence of A23187. However, even in the presence of the ionophore, neither the thapsigargin-insensitive nor thapsigarginsensitive $\mathrm{Ca}^{2+}$-ATPase could be reproducibly measured across the gradient against the high background values. As shown in Figure 4(a), the non-ionic detergent $C_{12} E_{8}$, known to activate ER $\mathrm{Ca}^{2+}$-ATPases [25,52], did produce an activation in total microsomes, reducing the $\mathrm{Ca}^{2+}$-independent background to $63 \%$.
However, this $\mathrm{C}_{12} \mathrm{E}_{8}$-induced activation rendered the activity largely insensitive to thapsigargin.

The degree of experimental difficulty presented by high levels of $\mathrm{Ca}^{2+}$-independent background in adrenal medulla microsomes is clearly brought out by a comparison with the contrasting results obtained using sarcoplasmic reticulum vesicles from rabbit skeletal muscle (Figure 4b). Per unit protein, sarcoplasmic reticulum $\mathrm{Ca}^{2+}$-ATPase was found to be about 900 -fold more enriched than the corresponding activity in adrenal medulla. As expected, essentially all sarcoplasmic reticulum ATPase activity was found to be $\mathrm{Ca}^{2+}$-dependent and thapsigargin-sensitive [13]. In addition, it may be seen that $\mathrm{C}_{12} \mathrm{E}_{8}$ did not abolish thapsigargin-induced inhibition of sarcoplasmic reticulum $\mathrm{Ca}^{2+}$ ATPase. (Maximally activating detergent/protein ratios were employed for both adrenal medulla and muscle microsomes. However, the inhibition of sarcoplasmic reticulum $\mathrm{Ca}^{2+}$-ATPase by thapsigargin was no less pronounced at $\mathrm{C}_{12} \mathrm{E}_{8}$ concentrations equal to, or exceeding, that used for the adrenal medulla microsomes, up to $2 \mathrm{mg} / \mathrm{ml}$.) The differential effects of $\mathrm{C}_{12} \mathrm{E}_{8}$ in the two types of preparations may reflect the more complex nature (involving more SERCA-subtypes) of $\mathrm{Ca}^{2+}$-ATPase activity in adrenal medulla.

\section{Is there a thapsigargin-insensitive component of $\mathrm{Ca}^{2+}$ uptake to non-mitochondrial $\mathrm{Ca}^{2+}$ stores in adrenal medulla chromaftin cells?}

A proportion (40-60\%, varying between the different microsome preparations) of $\mathrm{Ca}^{2+}$ uptake in the total microsomes (P3) could not be inhibited by thapsigargin. A thapsigargin-insensitive $\mathrm{Ca}^{2+}$. ATPase was suggested to be responsible for $\mathrm{Ca}^{2+}$ loading of the caffeine-sensitive store in isolated chromaffin cells [10]. In view of the uniformly high sensitivity of SERCA ATPases to thapsigargin inhibition [53], the presence of such a thapsigargin-insensitive, internal $\mathrm{Ca}^{2+}$ pump in chromaffin cells might signify a novel type of $\mathrm{Ca}^{2+}$-store-associated ATPase. However, in view of the evidence discussed below, the presence of such a thapsigargininsensitive $\mathrm{Ca}^{2+}$-store pump in chromaffin cells appears unlikely. This evidence stems from experiments on the microsomal fractions as well as from experiments on isolated, permeabilized cells.

At the subcellular fractionation level, four observations indicate the thapsigargin-insensitive $\mathrm{Ca}^{2+}$ pump to be associated with plasma membranes rather than with the non-mitochondrial $\mathrm{Ca}^{2+}$ stores: (1) A highly significant statistical correlation between the distribution of the thapsigargin-insensitive component of $\mathrm{Ca}^{2+}$ uptake and that of plasma membranes, known to possess a thapsigargin-insensitive $\mathrm{Ca}^{2+}$ pump [32] (Figures 3a and 3c). (2) In a direct visualization of the plasma membrane $\mathrm{Ca}^{2+}$ pump by immunostaining, the staining intensity peaked in those fractions exhibiting the maximal enrichment in the thapsigargin-insensitive $\mathrm{Ca}^{2+}$ uptake (Figure 3b). (3) In contrast, it is apparent from Figures 2(a) and 2(b) that both Ins $P_{3}$-sensitive and ryanodinesensitive (caffeine-sensitive) receptor-channels had a distribution profile clearly distinct from the thapsigargin-insensitive component of $\mathrm{Ca}^{2+}$ uptake, as well as from the PMCA-like immunoreactivity. It is important to stress that because of an essentially complete recovery $(96 \%)$ of the thapsigargin-insensitive component, we can rule out that a fraction of the thapsigargininsensitive $\mathrm{Ca}^{2+}$ uptake, co-migrating with major $\mathrm{Ca}^{2+}$-storereceptor-channels, remained undetected on the gradient. (4) Vanadate was 4.8 times more potent as an inhibitor of the thapsigargin-insensitive, than of thapsigargin-sensitive, component of $\mathrm{Ca}^{2+}$ uptake. Since vanadate is known to act as a more potent inhibitor of plasma membrane-type [32,39-41], as compared with ER-type [25,42], $\mathrm{Ca}^{2+}$ pumps, this observation again 
indicates the thapsigargin-insensitive component of $\mathrm{Ca}^{2+}$ uptake to be associated with plasma membranes rather than with internal $\mathrm{Ca}^{2+}$ stores.

In experiments using isolated chromaffin cells, the permeabilized cells were clearly able to sequester extracellular $\mathrm{Ca}^{2+}$ in an ATP-dependent manner. The cells also displayed the ability to release some of this sequestered $\mathrm{Ca}^{2+}$ following an appropriate challenge of either $\operatorname{Ins} P_{3}$ or ryanodine receptors. In the present experiments, we used caffeine to activate the ryanodine receptor. Caffeine has been widely employed for this purpose in a number of systems [54], including chromaffin cells $[7,8,12,44]$. The amplitudes of Ins $P_{3}$ - and caffeine-induced $\mathrm{Ca}^{2+}$ transients in our hands were approximately $10 \%$ and $15 \%$ of the corresponding published values $[8,12]$. The amount of $\mathrm{Ca}^{2+}$ released upon activation of Ins $P_{3}$ or ryanodine receptors depends on a number of factors, including concentrations of free $\mathrm{Ca}^{2+}$ in the external and luminal spaces of $\mathrm{Ca}^{2+}$ stores $[44,54,55]$. In this connection, a significant difference may be the EGTA wash of the cells included in our, but not in the earlier corresponding preparation, protocols $[8,12]$. Conceivably, removal by EGTA of bound $\mathrm{Ca}^{2+}$ from $\mathrm{Ca}^{2+}$-binding proteins in the stores might have increased their subsequent capacity for chelation of $\mathrm{Ca}^{2+}$ in the course of the ATP-dependent uptake. An increased store loading following $\mathrm{Ca}^{2+}$ depletion by EGTA in chromaffin cells has indeed been described [56]. Such increased capacity for $\mathrm{Ca}^{2+}$ binding to the proteins within the stores could prevent the intraluminal rise of free $\mathrm{Ca}^{2+}$ to the level necessary to 'sensitize' the $\operatorname{Ins} P_{3}$ or ryanodine receptors.

The approximate Ins $P_{3} /$ caffeine response amplitude ratios were 0.6 in the present study, as compared with between 0.8 [12] and 2.5 [8] in some of the earlier studies. The responses observed by us were quite reproducible, and their amplitudes rather similar between independent cell preparations. Accordingly, the quoted response means were taken over such independently prepared cell batches. Hence, we conclude that under the conditions of the present work, the Ins $P_{3}$-sensitive and caffeinesensitive $\mathrm{Ca}^{2+}$ stores were functional in the permeabilized cells. When thapsigargin was added before ATP, subsequent $\mathrm{Ca}^{2+}$ uptake was abolished, and no $\mathrm{Ca}^{2+}$ release could be evoked from the stores either by Ins $P_{3}$ or caffeine (Figure $6 \mathrm{c}$ ). Thus, no $\mathrm{Ca}^{2+}$ loading could be started in a thapsigargin-insensitive manner. Conversely, when thapsigargin was added during the uptake phase, all $\mathrm{Ca}^{2+}$ taken up could be released in a course of a slow leak (Figure 6d). Such quantitative release of accumulated $\mathrm{Ca}^{2+}$ following addition of thapsigargin is in agreement with results reported by Stauderman et al. [12].

Based on the sum of the discussed evidence, we suggest that the thapsigargin-insensitive, vanadate-sensitive $\mathrm{Ca}^{2+}$ pump in chromaffin cells is associated with plasma membranes, while the thapsigargin-sensitive $\mathrm{Ca}^{2+}$-ATPases are responsible for $\mathrm{Ca}^{2+}$ loading to the $\operatorname{Ins} P_{3}$-sensitive, as well as caffeine-sensitive stores, as observed both in the microsomal fractions and in permeabilized cells. This conclusion is different from the suggestion by Robinson and Burgoyne [10], who proposed a thapsigargininsensitive $\mathrm{Ca}^{2+}$-ATPase to be associated with the caffeinesensitive store in adrenal chromaffin cells. However, in the experiments of Robinson and Burgoyne [10], thapsigargin was always added after the stores had been allowed to fill. Their proposal is based on the fact that this addition of thapsigargin inhibited a subsequent response to $\operatorname{Ins} P_{3}$, but not to caffeine. However, a slower $\mathrm{Ca}^{2+}$ leak from the caffeine-sensitive, as compared with the Ins $P_{3}$-sensitive store, might cause sufficient $\mathrm{Ca}^{2+}$ to remain in the former following an arrest of the thapsigargin-sensitive pump to allow a caffeine-induced release. This possibility was also noted recently by Pozzan et al. [3], who cited results from a number of studies consistent with a heterogeneity of leak rates in various types of thapsigargin-sensitive $\mathrm{Ca}^{2+}$ pools [57-59].

\section{Comparison of the distribution of the Ins $P_{3}$ and ryanodine receptors and $\mathrm{Ca}^{2+}$-ATPases in submicrosomal fractions of adrenal medulla and cerebellum}

Nori et al. [45] and Villa et al. [46] have used continuous sucrose gradients $(20-42 \%$ and $15-50 \%$ respectively) to study the localization of $\mathrm{Ca}^{2+}$-store proteins in microsomal fractions of rat cerebellum. Nori et al. used ligand binding (Ins $P_{3}$ or ryanodine) as well as immunodetection to probe the distribution of $\mathrm{Ca}^{2+}$. store-receptor channels across the gradients. The binding profiles for the two ligands were different, with the peak of Ins $P_{3}$ receptor occupying $31-36 \%$, and that of ryanodine receptor $23-27 \%$ sucrose regions, with another possible ryanodine-binding peak at $40 \%$ sucrose. While generally a similar biphasic ryanodinebinding profile was found by Villa et al., their $\operatorname{Ins} P_{3}$ receptor immunostaining suggested a broad uniform distribution over approximately $20-50 \%$ sucrose. A comparison of these results from rat cerebellar microsomes with the present data indicates that in the microsomes from bovine adrenal medulla, $\operatorname{Ins} P_{3}$ and ryanodine receptors are associated with $\mathrm{Ca}^{2+}$-store compartments sedimenting over a narrower and heavier range of sucrose concentrations. Apart from any species-related differences, this greater heterogeneity of cerebellar $\mathrm{Ca}^{2+}$ stores may not be surprising, considering their origin in a tissue of more complex composition than adrenal medulla. While more than $80 \%$ of tissue mass in the latter is contributed by chromaffin cells [60], numerous types of neurons and glial cells determine the composition of cerebellar microsomal membranes. This composition would be heavily influenced by the material originating in the Purkinje cells, owing to their large size and richly developed internal compartments involved in $\mathrm{Ca}^{2+}$ signalling. The complexity and specializations of Purkinje cell (e.g. cisternal stacks, spine apparatus, calciosomes [46,61]) might surpass the ultrastructural architecture of $\mathrm{Ca}^{2+}$ stores in chromaffin cells. However, this interpretation will remain tentative until adequate immunocytochemical visualization of chromaffin cell $\mathrm{Ca}^{2+}$ stores can be achieved at the ultrastructural level.

We are greatly indebted to Miss E. Engberg and I. Kjeldsen for their expert technical assistance, and to Miss $E$. Engberg in particular for invaluable help in isolation of chromaffin cells. We are also indebted to Dr. S. B. Christensen for the gift of thapsigargin. This work was supported by the Danish Biotechnology Research Program, Nordisk Insulin Foundation, Aage-Louis Hansen's Foundation and Dir. J. Madsen and Spouse 0. Madsen's Foundation. We thank the NV-OX company for kindly providing us with the access and help to obtain bovine adrenal glands. J.-C.J.P., C.C. and D.M. were students working towards cand. scient. degree in biochemistry during parts of this study.

\section{REFERENCES}

1 Cheek, T. R. (1991) Curr. Opin. Cell Biol. 3, 199-205

2 Berridge, M. J. (1993) Nature (London) 361, 315-325

3 Pozzan, T., Rizzuto, R., Volpe, P. and Meldolesi, J. (1994) Physiol. Rev. 74, 595-636

4 Burk, S. E., Lytton, J., MacLennan, D. H. and Shull, G. E. (1989) J. Biol. Chem. 264, 18561-18568

5 Mikoshiba, K. (1993) Trends Pharmacol. Sci. 14, 86-89

6 Sorrentino, V. and Volpe, P. (1993) Trends Pharmacol. Sci. 14, 98-103

7 Burgoyne, R. D., Cheek, T. R., Morgan, A., O'Sullivan, A. J., Moreton, R. B., Berridge, M. J., Mata, A. M., Colyer, J., Lee, A. G. and East, J. M. (1989) Nature (London) 342, 72-74

8 Cheek, T. R., Barry, V. A., Berridge, M. J. and Missiaen, L. (1991) Biochem. J. 275, 697-701

9 Robinson, I. M., Cheek, T. R. and Burgoyne, R. D. (1992) Biochem. J. 288, 457-463

10 Robinson, I. M. and Burgoyne, R. D. (1991) J. Neurochem. 56, 1587-1593 
11 Robinson, I. M. and Burgoyne, R. D. (1991) FEBS Lett. 289, 151-154

12 Stauderman, K. A., McKinney, R. A. and Murawsky, M. M. (1991) Biochem. J. 278, $643-650$

13 Inesi, G. and Sagara, Y. (1992) Arch. Biochem. Biophys. 298, 313-317

14 Inesi, G. and Sagara, Y. (1994) J. Membr. Biol. 141, 1-6

15 Cheek, T. R. and Thastrup, 0. (1989) Cell Calcium 10, 213-221

16 Cheek, T. R., Moreton, R. B., Berridge, M. J. and Thastrup, O. (1989) Biochem. Soc. Trans. 17, 94-95

17 Mathiasen, D., Røssum, L. M., Robinson, I. M., Burgoyne, R. D., East, J. M., Møller, M., Rasmussen, H. N. and Treiman, M. (1993) Int. J. Biochem. 25, 641-652

18 De Meis, L. and Hasselbach, W. (1971) J. Biol. Chem. 246, 4759-4763

19 Laemmli, U. K. (1970) Nature (London) 227, 680-685

20 Colyer, J., Mata, A. M., Lee, A. G. and East, J. M. (1989) Biochem. J. 262, 429-447

21 Lai, F. A., Dent, M., Wickenden, C., Xu, L., Kumari, G., Misra, M., Lee, H. B., Sar, M. and Meissner, G. (1992) Biochem. J. 288, 553-564

22 Maeda, N., Niinobe, M., Inoue, Y. and Mikoshiba, K. (1989) Dev. Biol. 133, 67-76

23 Furuichi, T., Yoshikawa, S., Miyawaki, A., Wada, K., Maeda, N. and Mikoshiba, K. (1989) Nature (London) 342, 32-38

24 Föhr, K. J., Warchol, W. and Gratzl, M. (1993) Methods Enzymol. 221, 149-157

25 Michelangeli, F., Divirgilio, F., Villa, A., Podini, P., Meldolesi, J. and Pozzan, T. (1991) Biochem. J. 275, 555-561

26 Burgoyne, R. D., Morgan, A. and O'Sullivan, A. J. (1988) FEBS Lett. 238, 151-155

27 Williams, D. A. and Fay, F. S. (1990) Cell Calcium 11, 75-83

28 Böhlen, P., Stein, S., Dairman, W. and Udenfriend, S. (1973) Arch. Biochem. Biophys. 155, 213-220

29 Supattapone, S., Danoff, S. K., Theibert, A., Joseph, S. K., Steiner, J. and Snyder, S. H. (1988) Proc. Natl. Acad. Sci. U.S.A. 85, 8747-8750

30 Zorzato, F., Fujii, J., Otsu, K., Phillips, M., Green, N. M., Lai, F. A., Meissner, G. and MacLennan, D. H. (1990) J. Biol. Chem. 265, 2244-2256

31 Kao, L..S. and Cheung, N. S. (1990) J. Neurochem. 54, 1972-1979

32 Carafoli, E. (1991) Physiol. Rev. 71, 129-153

33 Siegel, G. J., Stahl, W. L. and Swanson, P. D. (1981) in Basic Neurochemistry (Siegel, G. J., Albers, R. W., Agranoff, B. W. and Katzman, X., eds.), pp. 107-143, Little, Brown and Company, Boston

34 Meldolesi, J., Madeddu, L. and Pozzan, T. (1990) Biochim. Biophys. Acta 1055 $130-140$

35 Sottocasa, G. L., Kuylenstierna, B., Ernster, L. and Bergstrand, A. (1967) J. Cell Biol. 32, 415-438

36 Fiskum, G. and Lehninger, A. L. (1982) in Calcium and Cell Function (Cheung, W. Y., ed.), vol. II, pp. 39-80, Academic Press, New York

Received 5 December 1994; accepted 21 December 1994
37 Blaustein, M. P. (1988) in Calcium in Drug Actions. Handbook of Experimental Pharmacology (Baker, P. F., ed.), vol. 83, pp. 275-304, Springer-Verlag, Berlin, Heidelberg

38 Seiler, S. and Fleischer, S. (1988) Methods Enzymol. 157, 26-36

39 Bond, G. H. and Hudgins, P. M. (1980) Biochim. Biophys. Acta 600, 781-790

40 Rossi, J. P. F. C., Garrahan, P. J. and Rega, A. F. (1981) Biochim. Biophys. Acta 648, 145-150

41 Barrabin, H., Garrahan, P. J. and Rega, A. F. (1980) Biochim. Biophys. Acta 600 $796-804$

42 Lytton, J., Westlin, M., Burk, S. E., Shull, G. E. and MacLennan, D. H. (1992) J. Biol. Chem. 267, 14483-14489

43 Palade, P. (1987) J. Biol. Chem. 262, 6135-6141

44 Cheek, T. R., Moreton, R. B., Berridge, M. J., Stauderman, K. A., Murawsky, M. M. and Bootman, M. D. (1993) J. Biol. Chem. 268, 27076-27083

45 Nori, A., Villa, A., Podini, P., Witcher, D. R. and Volpe, P. (1993) Biochem. J. 291 , 199-204

46 Villa, A., Sharp, A. H., Racchetti, G., Podini, P., Bole, D. G., Dunn, W. A., Pozzan, T. and Snyder, S. H. (1992) Neuroscience 49, 467-477

47 Volpe, P., Villa, A., Damiani, E., Sharp, A. H., Podini, P., Snyder, S. H. and Meldolesi, J. (1991) EMBO J. 10, 3183-3189

48 Tunwell, R. E. A., Conlan, J. W., Matthews, I., East, J. M. and Lee, A. G. (1991) Biochem. J. 279, 203-212

49 Plessers, L., Eggermont, J. A., Wuytack, F. and Casteels, R. (1991) J. Neurosci. 11, $650-656$

50 Miller, K. K., Verma, A., Snyder, S. H. and Ross, C. A. (1991) Neuroscience 43, 1-9

51 Christensen, S. B., Andersen, A., Poulsen, J.C. J. and Treiman, M. (1993) FEBS Lett. 335, 345-348

52 Le Maire, M., Møller, J. V. and Tanford, C. (1976) Biochemistry 15, 2336-2342

53 Lytton, J., Westlin, M. and Hanley, M. R. (1991) J. Biol. Chem. 266, 17067-17071

54 Ehrlich, B. E., Kaftan, E., Bezprozvannaya, S. and Bezprozvanny, I. (1994) Trends Pharmacol. Sci. 15, 145-149

55 Missiaen, L., De Smedt, H., Parys, J. B. and Casteels, R. (1994) J. Biol. Chem. 269 , 7238-7242

56 Sui, A.-L. and Kao, L.-S. (1994) Neurochem. Res. 19, 753-759

57 Chu, A., Volpe, P., Costello, B. and Fleischer, S. (1986) Biochemistry 25, 8315-8324

58 Shoshan-Barmatz, V., Zhang, G. H., Garretson, L. and Krause-Friedmann, N. (1990) Biochem. J. 268, 699-705

59 Li, G., Milani, D., Dunne, M. J., Pralong, W. F., Theler, J. M., Petersen, O. H. and Wollheim, C. B. (1991) J. Biol. Chem. 266, 3449-3457

60 Phillips, J. H. (1982) Neuroscience 7, 1595-1609

61 Satoh, T., Ross, C. A., Villa, A., Supattapone, S., Pozzan, T., Snyder, S. H. and Meldolesi, J. (1991) J. Cell Biol. 111, 615-624 